\title{
Medida e Ordem: \\ Elementos do Universo Cósmico e Ético-Antropológico de Heráclito
}

Esmael Alves de Oliveira

\section{Resumo}

O universo humano é complexo e, em consonância com o pensamento heraclítico, só poderia ser compreendido levando-se em consideração seus diversos aspectos. É difícil, portanto, falar do âmbito propriamente humano sem levar em conta o aspecto cosmológico e sua estreita relação com o lógos universal. É importante ressaltar que, em Heráclito, a problemática do éthos não se dará de forma bem estruturada; no entanto, nada impede a tentativa de se pensar a questão ética evocando alguns elementos do pensamento do efesino, que contém já em germe aquilo que será aprofundado a partir da segunda metade do século v (com Sócrates e os sofistas) e que será tema de discussão de sucessivas gerações de pensadores.

Palavras-chave: Heráclito, medida, ordem, lógos, ética. 


\section{Heráclito de Éfeso: Vida e Obra}

Compreender a vida de Heráclito não constitui uma tarefa fácil devido à escassez de informações ou divergências entre os autores e as fontes, por serem tardias, não são muito confiáveis. A principal fonte que relata alguns aspectos gerais do pensamento heraclítico se encontra em Diógenes Laércio (séc III-IV d. C.).

Heráclito viveu, ao que tudo indica, entre os séc. VI e V a. G. e o auge de sua existência se deu, aproximadamente, na LXIX olimpíada (504-500 a.C.). Diz-se que Heráclito possuía um caráter altivo e melancólico, além de manifestar certa aversão à convivência social (misântropo). Desprezava o povo comum e manifestou críticas ferrenhas aos antigos poetas, aos pensadores de seu tempo e até mesmo à própria religião. A respeito, José Cavalcante de Souza comenta:

Recebeu o cognome de skoteinós, o obscuro. Formulou com vigor o problema da unidade permanente do ser diante da pluralidade e mutabilidade das coisas particulares e transitórias. Estabeleceu a existência de uma lei universal (o lógos), regedora de todos os acontecimentos particulares e fundamento da harmonia universal, harmonia feita de tensões opostas. ${ }^{\mathrm{I}}$

Segundo Kirk e Raven ${ }^{2}$, as únicas informações sobre a vida de Heráclito que são dignas de crédito referem-se ao seu local de origem, Éfeso, à sua descendência aristocrática e aos problemas de relacionamento com os seus concidadãos.

Alguns autores acreditam que Heráclito não chegou a atribuir um título à sua obra. É Diógenes Laércio ${ }^{3}$ que nos informa que uns a chamavam de As musas, outros de Da natureza. Ainda segundo Diógenes, a obra seria uma espécie de tratado dividido em três partes: o universo, a política e a teologia ${ }^{4}$. No que concerne à morte de Heráclito, o mesmo doxógrafo afirma ter ele morrido aos sessenta anos de idade tendo como causa a hidropisia (acumulação de líquido patológico em diversas partes do corpo).

Heráclito, apesar de não ter chegado à posteridade sua obra integral, possui em seus fragmentos um pensamento muito fecundo. Tentar pensar o homem

I Os pré-socráticos. Coleção Os Pensadores Trad. José Cavalcante de Souza et al. 4 ed. São Paulo: Nova Cultural, I989, p. 45 .

2 G. S. Kirk; J. E. Raven. Os flósofos pré-socráticos. Lisboa: Calouste Gulbenkian, I990, p. 85.

3 Diógenes Laércio. Vidas e doutrinas dos filósofos ilustres. Brasília: UNB, I988, p. 254.

4 idem, ib. p. 252. 
em sua estreita relação com a ética, em Heráclito, é estar aberto, sobretudo, às diversas possibilidades de interpretações do lógos, que enquanto lei universal rege todas as coisas, inclusive as ações humanas. Nesta perspectiva, o lógos pode ser compreendido de modos variados, e, certamente, a dimensão ética torna-se uma das formas principais de sua manifestação.

\section{A Ética Heraclítica ${ }^{5}$}

Não se pode abordar a questão ética em Heráclito sem se remeter à temática do lógos. Alguns autores chegam a afirmar ser este o problema fundamental de tal pensador. Torna-se necessário, portanto, uma pequena análise deste aspecto do pensamento heraclítico.

A palavra lógos possui diversos significados; porém, alguns especialistas, atentando para as dificuldades de tradução do termo em seu sentido original, preferem optar pela forma transliterada. É o caso de Damião Berge em seu estudo sobre Heráclito ${ }^{6}$. Segundo alguns filólogos, tal termo, na época de Heráclito, era usado com diferentes sentidos, e o próprio pensador o teria empregado, em sua obra, com diversidade de significações e conceituações. Haveria, portanto, muitas possibilidades de entendimento do termo.

O termo lógos não foi uma invenção de Heráclito, uma vez que ele já estava incorporado à literatura. Nos poemas homéricos, ele designava de uma maneira ampla a palavra humana, a narração, o canto; de modo mais restrito, o dizer dos heróis. Heráclito não o inventou; no entanto, deu-lhe uma nova configuração. Estendeu o lógos ao Todo, numa tentativa de tornar inteligível a regência ou o governo da Natureza. Nesse sentido, o lógos é uma explicitação da arkhé e também da phýsis, tendendo a conferir a esses termos uma inteligibilidade mais acessível. Heráclito, ao referir o lógos ao kósmos, quis tornar inteligível o próprio mundo humano; fez do lógos cósmico, da ordem universal, o modelo do lógos humano.

Segundo Manuel da Costa Freitas, a raiz do verbo légo, que origina o substantivo lógos, é leg. Légo indicava, originalmente, a ação de recolher mediante escolha, organizando o que se escolheu, ordenadamente. O verbo légo expressava o conjunto dessa ação, e não propriamente o falar e o dizer. Foi Homero quem redimen-

5 Os fragmentos utilizados seguem a tradução de José Cavalcante de Souza presente na Coleção "Os pensadores".

6 D. Berge. O logos heraclítico: introdução ao estudo dos fragmentos. Rio de Janeiro: INL, I969.

7 V.AA. Logos: enciclopédia luso-brasileira de filosofia. v. 3 Lisboa: Verbo, I99I.

Humanidades em Diálogo, vol i, N. I, NOV. 2007 IO5 
sionou esse significado originário, enquanto que Heráclito, mais tarde, e numa perspectiva semelhante, deu ao termo uma conotação filosófica enriquecendo-o com outros significados. Com Heráclito, o termo passou a expressar verbalmente tanto o pensamento humano quanto o princípio que governa o mundo ${ }^{7}$.

Diante das diversas possibilidades de significações de termo, Vianna afirma:

Temos a impressão de que, para Heráclito, manifesta-se-nos o lógos, nos domínios da natureza, como lei física; no terreno da ética, como princípio moral; no âmbito estatal, como lei política; na esfera do direito, como lei jurídica; na alma humana, como princípio racional. ${ }^{8}$

O lógos, no pensamento do efesino, também possuía um sentido figurado: "o fogo sempre vivo, acendendo-se e apagando-se em medidas" (frag. 30) 9 . Surge aqui um primeiro elemento que remete à questão ética: o lógos, como o fogo, que possui uma ordem intrínseca e que concede à phýsis (que abarca todas as coisas, inclusive o homem) uma medida certa, um métron.

Para alguns especialistas, o fogo pode ser compreendido como o modelo primitivo da matéria, como o fundamento constitutivo das coisas. Não se confundindo com uma substância primeira. Kirk e Raven dizem que o fogo de Heráclito não se relaciona com os elementos dos milésianos ${ }^{\mathrm{IO}}$. No entanto, outros pesquisadores acreditam ter o fogo muitos significados: princípio (arkhé), lógos (regulador), vir-a-ser (mudança) etc. No fragmento 94 ("Pois Hélios não transpassará as medidas; senão as Erínias, servas da Justiça, descobrirão"), a temática da desmedida humana pode ser retratada por meio de Hélios, divindade solar que representa o fogo. No pensamento mítico, as divindades interferem ativa e constantemente no universo humano. Neste sentido, completa o fragmento 64: "De todas as (coisas) o raio fulgurante dirige o curso". Nos dois fragmentos, a figura do sol tem um papel preponderante; no primeiro (frag. 94) é dito que nem Hélios escapa à ação das Erínias (divindades justiceiras), dando a entender que todo o kósmos é regulado por uma lei universal, ou seja, o mundo é um eterno fogo com uma regra inerente, própria. Ao quebrar este equilíbrio, o homem põe em risco a existência das coisas e a sua. A ação humana, sua intervenção, deve, portanto, ser regulada para que não exceda a medida e não cause transtornos à realidade na qual está inserido.

8 S. B. A. Vianna. "O estranho Heráclito de Éfeso”. In: Kriterion n. 69, Belo Horizonte: UfmG, I976, p. 5.

9 "Este mundo, o mesmo de todos os (seres), nenhum deus, nenhum homem o fez, mas era, é e será um fogo sempre vivo, acendendo-se em medidas e apagando-se em medidas".

Io G. S. Kirk; J. E. Raven. Os filósofos pré-socráticos. Lisboa: Calouste Gulbenkian, I990, p. 2002. 
A figura das Erínias dá uma conotação régio-divina aos instrumentos de controle das ações humanas. No segundo fragmento (64) é fornecida outra característica: o lógos (raio fulgurante) é o que dirige e orienta tudo o que existe, nada escapando ao seu domínio, ao seu controle, à sua medida.

Torna-se importante ressaltar que, nas relações sociais, os interesses coletivos (pólis) devem estar acima dos individuais (oikos), e esta é uma das características mais marcantes do comportamento social grego. A lei surge como um instrumento de manutenção da relativa paz social. Tudo o que possa abalar esta ordem física, política, social e cósmica, deve ser combatido. O fragmento 44 ("É preciso que lute o povo pela lei, tal como pelas muralhas") é bem claro: valorizar a lei. Os homens possuem responsabilidades e estas são atribuídas pela lei, bem como os direitos. Segundo Donaldo Schüler,

a lei é a condição para que diferentes possam conviver. A lei consente que o outro seja outro, protege-o. Lutar pela lei é bater-se pelo espaço em que contrários se confrontam, é lutar pela vida como ela é. Combater pela lei é bater-se pelo direito de diferentes serem o que são. ${ }^{\text {II }}$

Em outro sentido, lutar pela lei como pelas muralhas, é, sobretudo, valorizar algo que supera inclusive a segurança física. É de destaque a importância dada pelo efesino à lei. É ela que garante a coesão social, pois todos passam a ser responsáveis pela cidade (pólis). Para Heráclito, estas exigências excedem a capacidade humana, por isso torna-se necessário o auxílio daquilo que tudo dirige (lógos).

No próprio desenvolver da história, através dos processos cósmicos, os limites foram sendo impostos. Tudo possui uma ordem inerente, uma medida apropriada, é isto o que diz o fragmento 30 ao metaforizar o mundo como um fogo que se acende e se apaga na medida certa. O kósmos é uma totalidade que abarca em si todas as coisas, e o que garante que tudo mantenha uma ordem, uma medida, é o lógos. Aquilo que não possui uma ordem, um equilíbrio, uma sintonia, acaba por desfazer-se. Em Heráclito, todas as coisas estão interligadas e possíveis alterações que não obedeçam a determinados limites, acarretam o caos. As relações sociais, as relações políticas, a própria vida humana necessita de transformação, mas transformações que obedeçam aos limites e não acarretem uma completa desagregação. A palavra chave é medida. Todas as coisas estão sob uma ação moderada. O ouro (frag. 90) ${ }^{12}$

II D. Schüler. Heráclito e seu dis(curso). 2 ed. Porto Alegre: L\&PM, 200 I p. I86.

I2 "Por fogo se trocam todas as (coisas) e fogo por todas, tal como por ouro mercadorias e por mercadorias ouro". 
representa o poder, a distinção: todas as coisas são importantes, e possuem sua função e utilidade no todo. O que dita os papéis é o processo dinâmico do kósmos, que distribui equitativamente os papéis. O fogo (lógos) estabelece as possibilidades e os limites do homem, que não pode possuir tudo o que deseja. Existem critérios que devem ser seguidos.

Segundo esta linha de pensamento, os fragmentos 43 ("A insolência é preciso extinguir mais que o incêndio") e II9 ("O ético no homem [é] o demônio [e o demônio é o ético]") se complementam. Para não incidir no extremo, o homem precisa dominar a hýbris (insolência). Esta é responsável pelas grandes tragédias humanas. Mas como dominar algo que aparentemente é sem controle? Heráclito dá a resposta: o ético-demônio. O que seria o demônio (ou dáimon)? Alguns autores dizem que o termo representava uma espécie de inspiração divina (bom espírito), outros, contemporâneos, dizem tratar-se de uma consciência interior. Mas o que há de se destacar é sua estreita relação com a éthica (éthos). Juntos seriam responsáveis por garantir ao homem a manutenção da medida (métron), do equilíbrio, diante da possibilidade de extremos.

O termo dáimon está ligado a dáimones, e possui uma diversidade de significações. Segundo Valcicléia Pereira da Costa ${ }^{13}$, o termo está relacionado ao auxílio divino (uma divindade favorável que possibilita a quem a acompanha, usufruir de uma boa vida). A autora, citando Liddell-Scott e Festugière descreve que, etimologicamente, o termo dáimones deriva do verbo dividir, repartir, distribuir. Neste sentido, os dáimones seriam os distribuidores dos bens humanos. No entanto, este não parece ser seu único significado. Segundo Ghantraine, citado por Valcicléia Costa ${ }^{\mathrm{I}}$, o termo já aparece no vocabulário cretense com o sentido negativo de "espírito maligno", responsável pelas desventuras humanas.

Valcicléia Costa também salienta que inicialmente o dáimon, enquanto protetor, estaria ligado a uma idéia religiosa de distribuição concedida pelas divindades aos homens, às cidades e às regiões, muito embora adquirisse progressivamente um sentido não-religioso. Com o nascimento do pensamento filosófico, a concepção de dáimones sofreu algumas alterações. Houve, assim, uma distinção entre um bom dáimon (responsável pela felicidade) e um mau dáimon (responsável pela infelicidade), mas ambos agora situados no âmbito do agir humano (livre das concessões arbitrárias das divindades).

I3 V. P. Costa. O tópos da eudaimonía no discurso ético-político de Platão. Tese. São Paulo: Instituto de Ciências Humanas e Letras, Universidade Estadual de Campinas, 2004.

I4 idem, ib. p. 36 . 
Associar o ético com o dáimon é remeter-se a uma profundidade que só será mais bem evidenciada na filosofia socrático-platônica. Descer ao que há de mais profundo, infiltrar-se no interior escondido, é a base do caráter e das excelências dignas do lógos eterno. É do interior, de onde provêm as inspirações do dáimon, que emana a verdadeira postura ética. Não parece haver espaço para ouvir o daimoníaco num espaço dominado pelas confusões e imperfeições humanas. $\mathrm{O}$ lógos, que "nem diz nem oculta, mas dá sinais" (frag. 93), requer um discernimento adequado, diferenciado do vulgo. Para Damião Berge, o fragmento II9 representa um grande convite: "Que entrem, pois em seu interior, onde reside o lógos e lhes forma a consciência própria: este dirigir-lhes-á a vida"I5.

Enfim, a liberdade humana confronta-se com um universo, por vezes, conflituoso: o das possibilidades, que somente quando são levadas em consideração com uma postura madura e moderada (própria dos que se deixam conduzir pelo lógos universal), garantirão uma escolha não influenciada pelos excessos ou pela desmedida. Ao seguir as leis do lógos, que são necessárias e universais, o homem cumpre o que é próprio de sua natureza e aproxima-se do agir ético que se manifesta numa vida prudente e sábia ("perfeição" intelectual).

\section{Referências Bibliográficas}

Berge, D. O logos heraclítico: introdução ao estudo dos fragmentos. Rio de Janeiro: INL, I969.

Bornheim, G. Os filósofos pré-socráticos. I2 ed. São Paulo: Cultrix, 2003.

Burnet, J. O despertar da filosofia grega. Trad. Mario Gama. São Paulo: Siciliano, I994.

Costa, V. P. O tópos da eudaimonía no discurso ético-político de Platão. 2004 . $428 \mathrm{f}$. Tese (Doutorado em Filosofia) - Instituto de Giências Humanas e Letras, Universidade Estadual de Campinas, São Paulo.

Guthrie, W. K. G. Os flósofos gregos: de Tales a Aristóteles. Trad. Maria José Vaz Pinto. Lisboa: Presença, I987.

I5 D. Berge. O logos heraclítico: introdução ao estudo dos fragmentos. Rio de Janeiro: INL, I969, p. I8I. 
Medida e Ordem: Elementos do Universo Cósmico e Ético-Antropológico de Heráclito

Heráclito. Fragmentos contextualizados. Trad. Alexandre Costa. Rio de Janeiro: Difel, 2002.

Kirk, G. S; Raven, J. E. Os flósofos pré-socráticos. Trad. Carlos Alberto Louro Fonseca; Beatriz Rodrigues Barbosa; Maria Adelaide Pegado. Lisboa: Calouste Gulbenkian, I990.

LAÉRCiO, D. Vidas e doutrinas dos flósofos ilustres. Tradução Mário da Gama Kury. Brasília: UNB, I988.

V. AA. Logos: Enciclopédia Luso-Brasileira de Filosofia. Lisboa: Verbo, I99I. Vol 3.

Os pré-socráticos. Coleção Os Pensadores. Trad. José Cavalcante de Souza. et. al. 4 ed. São Paulo: Nova Cultural, I989.

Penedos, A. J. Introdução aos pré-socráticos. Porto: Rés, I984.

Sahüler, D. Heráclito e seu dis(curso). 2 ed. Porto Alegre: L\&PM, 200 I.

ViannA, S. B. A. "O estranho Heráclito de Éfeso”. In: Kriterion n. 69, Belo Horizonte: UFMG, I976.

ESMAEL Alves de Oliveira é graduando em filosofia pela UfAM e bolsista pelo GNPq. 